\title{
CHAPTER 14: NON-COMMERCIALLY EXPLORED Campomanesia spp. NATIVE FRUITS AS POTENTIAL SOURCE OF ANTIMICROBIAL COMPOUNDS
}

\author{
Silvani Verruck ${ }^{1}$; Anildo Cunha Junior ${ }^{2}$; Nei Fronza ${ }^{3}$; Jean Carlos Budke ${ }^{4}$; Sheila Mello da Silveira ${ }^{5}$
}

\begin{abstract}
Campomanesia eugenioides, Campomanesia xanthocarpa (Berg) and Campomanesia xanthocarpa var. littoralis comprises non-commercially explored native fruits from Brazil. Considering the scarcity of studies on the native fruits characterization from Campomanesia spp., the aim of the present study was to determine the antibacterial effects of $C$. xanthocarpa (Berg), C. eugenioides and C. xanthocarpa var. littoralis agains 15 strains of food-borne pathogens. The antibacterial tests demonstrated a high antibacterial activity for some of the Gram-positive bacteria tested, i.e., Bacillus cereus, Bacillus subtilis, Listeria monocytogenes, and Staphylococcus aureus. It is noteworthy that $C$. xanthocarpa var. littoralis fruit extract was the better against a more substantial number of bacteria. Finally, it was possible to report that phenolic and flavonoids compounds present in $C$. eugenioides, $C$. xanthocarpa and $C$. xanthocarpa var. littoralis could be strongly associated with the antibacterial activity observed.
\end{abstract}

Keywords: Campomanesia eugenioides, Campomanesia xanthocarpa var. littoralis, Campomanesia xanthocarpa, native fruit, antibacterial properties, bioactive compounds.

\section{Introduction}

Territorial extension, geographical position, soil and climatic conditions are conditions that makes Brazil as one of the world's largest fruit producers (BARROS et al., 2017). However, large production of few fruit species are taking over more area, and consequently, the population loses the chance to know native species and varying their diet. In this sense, several native species are not economically explored yet. These native species could offer rich and nutritious alternatives, that could be more widely used for in natura consumption or in the production of sweets, jams, juices and ice-creams (PEREIRA et al., 2013). Thus, several still little known species of fruit have been evaluated more recently as an alternative to traditional species (BRANDAO; ANJOS; BELL, 2017; PAZ et al., 2015).

The fruits belonging to the genus Campomanesia sp. Comprises several species that could be more explored (DONADO-PESTANA et al., 2018). The fruits are round and green in color when young and yellow and sweet when mature (VALLILO et al., 2008), and globose and smooth, measuring about 5.5 to $7 \mathrm{~mm}$ in diameter (LIMA et al., 2011). Some species such as C. xanthocarpa var. littoralis (D. Legrand) shows some different characteristic such as the green color attributed to the fruit when mature and their size (15 to $40 \mathrm{~mm}$ ) (BIAVATTI et al.,

\footnotetext{
${ }^{1}$ Dr ${ }^{\text {a }}$, Ciência e Tecnologia de Alimentos, Universidade Federal de Santa Catarina, silvani.verruck@ufsc.br

${ }^{2}$ MSc, Empresa Brasileira de Pesquisa Agropecuária, EMBRAPA Suínos e Aves, anildo.cujnha@embrapa.br

${ }^{3}$ Dr, Engenharia de Alimentos, Instituto Federal Catarinense, nei.fronza@ifc.edu.br

${ }^{4}$ Dr, Biologia, Universidade Regional Integrada do Alto Uruguai e das Missões, jean@uricer.edu.br

${ }^{5} \mathrm{Dr}^{\mathrm{a}}$, Engenharia de Alimentos, Instituto Federal Catarinense, sheila.silveira@ifc.edu.br
} 
2004). Campomanesia xanthocarpa (Berg) is one of the most popularly known and widespread species among the genus (BARBIERI et al., 2017). On the other hand, C. eugenioides is commonly confused with $C$. xanthocarpa because they have similar characteristics, but $C$.

eugenioides is not so well known and studied. Campomanesia species are traditionally used in as traditional medicine for the treatment of intestinal disorders (MOURA-COSTA et al., 2012).

Currently, consumers have appreciated the availability of more natural and healthier foods, which may also bring some health benefit. In addition, with the development of bacteria resistant to many antibiotics, there is a growing interest in the study of antimicrobial substances from natural products. These factors have collaborated to increase interest in the search for natural products that have biological activities such as antimicrobial activity (SILVEIRA et al., 2014).

In the light of these observations, Cardoso et al. (2010) in their study with fruits of $C$. pubensces and $C$. adamantium found representative values of minimum inhibitory concentration for Gram-positive, Gram-negative bacteria, and also yeasts. This ability can be related with the presence of bioactive compounds in the fruits, such as phenolic compounds with proven antibacterial activities (CUSHNIE; LAMB, 2011; DRAGIŠIĆ MAKSIMOVIĆ et al., 2013). These compounds could be related with DNA molecule damage and with interferences on the reconstitution of damaged cell membranes (DRÖGE, 2002). Thus, considering the scarcity of studies on the native fruits characterization from Campomanesia spp., the aim of the present study was to determine the antibacterial effects of C.xanthocarpa (Berg), C. eugenioides and C. xanthocarpa var. littoralis agains 15 strains of food-borne pathogens.

\section{Material and Methods}

\section{Location description and collection of samples}

Riped C. eugenioides (Campomanesia eugenioides), C. xanthocarpa (Campomanesia xanthocarpa (Berg)) and C. xanthocarpa var. littoralis (Campomanesia xanthocarpa var. littoralis (D. Landrum)) fruits were collected in the West region of Santa Catarina State, Brazil, at latitude $27^{\circ} 14^{\prime} 2^{\prime \prime} \mathrm{S}$ and longitude $52^{\circ} 1^{\prime} 40^{\prime \prime} \mathrm{W}$ of Greenwich. The vouchers specimens were deposited at the Herbário do Vale do Taquari (HVAT, Lageado, Rio Grande do Sul, Brazil) and at the Herbário Padre Balduíno Rambo (HPBR, Erechim, Rio Grande do Sul, Brazil) as presented in Table 1. All the samples were collected when fully mature and were preselected considering the absence of visible injury, infections and color uniformity. Moreover, the fruits 
were freeze-dried with all the edible parts (skin, pulp, and seeds) and processed in a knife mill (Tecator, Knifetec 1095 model). The powders obtained were vacuum sealed in plastic bags and stored at a temperature of $-18 \pm 0.2{ }^{\circ} \mathrm{C}$ until analyzed.

Table 1. Campomanesia eugenioides, Campomanesia xanthocarpa (Berg) and Campomanesia xanthocarpa var. littoralis (D. Landrum) studied in the present work.

\begin{tabular}{|c|c|c|c|}
\hline $\begin{array}{l}\text { Registry } \\
\text { number }\end{array}$ & $\begin{array}{c}\text { Popular } \\
\text { name }\end{array}$ & Scienctific name & Collection location \\
\hline HVAT 2612 & Guabiroba & Campomanesia eugenioides & $\begin{array}{l}\text { Concórdia, SC, } 27^{\circ} 18^{\prime} 46^{\prime \prime} \\
\text { South, } 51^{\circ} 59^{\prime} 16^{\prime \prime} \text { West, } \\
\text { Brazil }\end{array}$ \\
\hline $\begin{array}{l}\text { HPBR } \\
11579\end{array}$ & $\begin{array}{l}\text { Guabiroba do } \\
\text { mato }\end{array}$ & $\begin{array}{l}\text { Campomanesia xanthocarpa } \\
\text { (Berg) }\end{array}$ & $\begin{array}{l}\text { Concórdia, SC, } 27^{\circ} 12^{\prime} 01 \text { ', } \\
\text { Southl, } 52^{\circ} 011^{\prime} 58^{\prime} \text { 'West, } \\
\text { Brazil. }\end{array}$ \\
\hline $\begin{array}{l}\text { HPBR } \\
11580\end{array}$ & $\begin{array}{l}\text { Guabiroba } \\
\text { verde }\end{array}$ & $\begin{array}{l}\text { Campomanesia xanthocarpa } \\
\text { var. littoralis (D. Landrum) }\end{array}$ & $\begin{array}{l}\text { Concórdia, SC, } 27^{\circ} 14^{\prime} 3^{\prime \prime} \\
\text { South, } 52^{\circ} 1^{\prime} 43^{\prime \prime} \text { West, } \\
\text { Brazil. }\end{array}$ \\
\hline
\end{tabular}

Source: Herbário do Museu de Ciências Naturais da UNIVATES (HVAT, Lajeado, RS) and Herbário Padre Balduíno Rambo da URI (HPBR, Erechim, RS).

\section{Freeze dry}

Initially, the whole fruits (about two kilos) were washed with distilled water and crushed in a mini-processor to obtain a homogeneous mass (pulp). The pulp was distributed in aluminum trays and frozen in a freezer at $-18{ }^{\circ} \mathrm{C}$ for 24 hours. Then, the samples were dehydrated in a lyophilizer (Liobrás LP810, SP, Brazil). The humidity was determined by gravimetry. The dry samples were processed in a knife mill (Tecator, model Knifetec 1095, Germany), vacuum packed and stored at $-18^{\circ} \mathrm{C}$ until the extract preparation.

\section{Extract preparation}

The extract of each fruit species was prepared prepared with freeze-dried fruit and ethanol: water 80:20 (v/v) in a mass/solvent ratio of 1:5 to obtain the hydroalcoholic extract by exhaustive maceration with solvent exchange at 24, 48, 72 and 192 hours. The extraction was carried out under agitation in an orbital plate (Etica, 109-2-E model, São Paulo, Brazil) at room temperature without incidence of light. The extract was filtered and rota-evaporated $\left(40 \pm 1^{\circ} \mathrm{C}\right)$ until dryness and dissolved in $100 \mathrm{~mL}$ of dimethyl sulfoxide (DMSO). All the extracts were stored in the dark at $4 \pm 1^{\circ} \mathrm{C}$ until analyzed.

\section{Evaluation of the antibacterial activity}


Microorganisms. Antibacterial activity was evaluated for the following strains: Bacillus cereus ATCC 11778, Bacillus subtilis ATCC 6633, Enterobacter aerogenes ATCC 13048, Escherichia coli ATCC 25922, Listeria monocytogenes ATCC 19117, Listeria monocytogenes serotype 2 ATCC 19112, Proteus vulgaris ATCC 13315, Pseudomonas aeruginosa ATCC 27853, Salmonella Enteritidis ATCC 13076, Salmonella Typhimurium ATCC 14028, Shigella sonnei ATCC 25931, Staphylococcus aureus ATCC 29213, Staphylococcus aureus ATCC 6538, Staphylococcus aureus ATCC 25923 and Yersinia enterocolitica ATCC 9610.

Microorganism suspension standardization. Bacterial cultures were grown on 5\% sheep red blood agar. Following the initial incubation, 3-5 isolated colonies were suspended in $10 \mathrm{ml}$ of tryptose soy broth (TSB) and incubated at $35 \pm 2{ }^{\circ} \mathrm{C}$ for 2 to 6 hours, to obtain an actively growing culture. This inoculum was diluted in $0.9 \%$ saline solution to a concentration

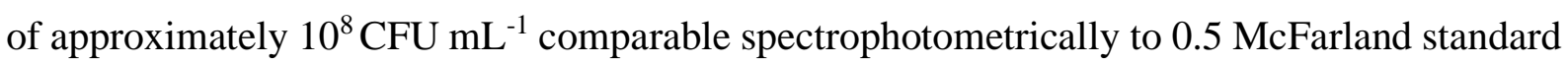
at $625 \mathrm{~nm}$. For the agar disc diffusion assay and the minimum inhibitory concentration determination, bacterial solutions of $10^{7} \mathrm{CFU} \mathrm{mL} \mathrm{mL}^{-1}$ were employed.

Agar disc diffusion method. The agar disc diffusion method was employed for the screening of antibacterial activities of the extracts of the fruit according to the Clinical and Laboratory Standards Institute (CLSI, 2019b). The test was performed in sterile Petri dishes (90 $\mathrm{mm}$ diameter) containing Mueller-Hinton agar medium (Difco, Sparks, USA). Briefly, the tested microorganism suspension was spread with a sterile swab on the MH agar. The extracts $\left(100 \mathrm{mg} \mathrm{mL}^{-1}\right)$ absorbed on sterile paper discs $\left(25 \mu \mathrm{L}\right.$ per disc of $9 \mathrm{~mm}$ diameter and $250 \mathrm{~g} \mathrm{~m}^{2-}$ ${ }^{1}$ ) were placed on the surface of the media previously inoculated and then incubated at $35 \pm 2$ ${ }^{\circ} \mathrm{C}$ for $24 \mathrm{~h}$. After the zone diameter of the inhibition was measured and expressed in $\mathrm{mm}$. Commercial discs of ampicillin (10 mg per disc) and chloramphenicol (30 mg per disc) were used as positive controls and disks containing DMSO $(25 \mu \mathrm{L})$ as a negative control. All tests were performed in triplicate. The inhibition was classified as strongly inhibitory, moderately inhibitory or not inhibitory according to Carović-Stanko et al. (2010). Minimum inhibitory concentrations were recorded for the extracts that showed positive antibacterial activity.

Minimum inhibitory concentration (MIC): broth microdilution. MICs were determined according to the method proposed by CLSI (CLSI, 2019a), with some modifications. In the microplate, serial dilutions of the extracts were made directly to the wells in the first row until the eighth row with sterile DMSO, resulting in concentrations that varied from $100 \mathrm{mg} \mathrm{mL}^{-1}$ to $0.75 \mathrm{mg} \mathrm{mL}^{-1}$. Ninety microliters of MHB, $10 \mu \mathrm{L}$ of the diluted tested solution and $10 \mu \mathrm{L}$ of the previously standardized microorganism suspension were added to 
each well, and the plate was incubated at $35 \pm 2{ }^{\circ} \mathrm{C}$ for $24 \mathrm{~h}$. It was assured the sterility control (MHB added of DMSO and without inoculum) and growth control (MHB added of DMSO and inoculum). Microbial growth was detected and confirmed with the addition of $20 \mu \mathrm{L}$ of an aqueous solution of triphenyltetrazolium chloride (TTC, $0.5 \%, \mathrm{w} / \mathrm{v}$ ), with one hour of additional incubation. All analyses were carried out in triplicate and expressed in $\mathrm{mg} \mathrm{mL}^{-1}$.

Minimum bactericidal concentration $(\mathbf{M B C})$ : To determine the MBCs the method proposed by Celiktas et al. (CELIKTAS et al., 2007) was used, with some modifications. For this, $10 \mu \mathrm{L}$ of the suspension in which was not microbial growth on the MIC assay were plated on TSA. The plates were incubated at $35 \pm 2{ }^{\circ} \mathrm{C}$ for $24 \mathrm{~h}$. The lowest concentration of the extract at which no growth of microorganisms was observed was considered the MBC. All tests were performed in triplicate and expressed in $\mathrm{mg} \mathrm{mL}^{-1}$.

\section{Statistical analysis}

The significance of the differences between the means of the samples was determined by analysis of variance (ANOVA) followed by Tukey's test (5\% significance). All statistical analyses were performed using the software STATISTICA version 13.3 (StatSoft Inc., Tulsa, OK, USA).

\section{Results and Discussion}

The antibacterial activities of $C$. eugenioides, C. xanthocarpa (Berg), and $C$. xanthocarpa var. littoralis fruits extracts were evaluated against seven Gram-positive and eight Gram-negative bacterial strains. Considering a future use of the extracts of the fruit as a possible food additive, these microorganisms were chosen because they are considered some of the most common food-borne pathogens. Thus, the results of the agar diffusion assay, presented in Table 2 , showed that the three extracts had no antibacterial activity against the eight species of Gramnegative bacteria tested. In accordance with Malanovic and Lohner (2016), Gram-negative bacteria present in their cell wall a lipopolysaccharide membrane that can interfere with some of these antibacterial substances blocking its activity.

Remarkably, all Gram-positive bacteria tested in the present study were susceptible to the three fruit extracts (Table 2). According to the classification of Carović-Stanko et al. (2010), the antibacterial activity can be classified in the following three categories: $>15 \mathrm{~mm}$ zone of inhibition was strongly inhibitory; $10-15 \mathrm{~mm}$ zone of inhibition was moderately inhibitory, and $<10 \mathrm{~mm}$ was not inhibitory. Taking this into account, $C$. eugenioides showed strong inhibitory effect against Listeria monocytogenes serotype 2 (Figure 1) and Staphylococcus aureus ATCC 
6538 (Figure 2). Also, C. xanthocarpa (Berg) showed strong inhibitory effect against S. aureus ATCC 29213 (Figure 2), while C. xanthocarpa var. littoralis showed strong inhibitory effect against Bacillus subtilis (Figure 3), L. monocytogenes serotype 2 (Figure 1), S. aureus ATCC 6538 and S. aureus ATCC 25923 (Figure 2). The fruits extract moderately inhibited all other Gram-positive bacteria. Thus, C. xanthocarpa var. littoralis fruit extract demonstrated high inhibitory activity against a more substantial number of Gram-positive bacteria.

Listeria monocytogenes species is known to be potentially pathogenic to humans and animals, causing gastrointestinal disorders, septicemia, abortion and, in more serious cases, death. They grow in a very wide temperature range (from 1 to $45^{\circ} \mathrm{C}$ ), which makes their control difficult (RYSER; DONNELLY, 2001). The growth of S. aureus in food also poses a great risk to human health because several strains of this species produce enterotoxins. Contaminations by $S$. aureus are among the main causes of foodborne diseases in the world (LANCETTE; BENNET, 2001). According to Ahmad, Mehmood and Mohammad (1998), fruits are popularly used as natural antimicrobials for the treatment of bacteriosis in Ayurvedic medicine. These authors reported zones of inhibition greater than $20 \mathrm{~mm}$ for Indian gooseberry, Haritaki and Bibhitaka, against S. aureus, B. subtilis, E. coli, P. aeruginosa, S. Typhimurium and P. vulgaris.

C. eugenioides and C. xanthocarpa var. littoralis showed moderate activity against Bacillus cereus, and these results did not differ significantly $(\mathrm{p}<0.05)$ from the zone of inhibition presented by the antibiotic ampicillin $(14.7 \mathrm{~mm})$ used as a positive control. Al-Zoreky (2009) reported antimicrobial activity of a methanolic extract of pomegranate peel against against L. monocytogenes, S. aureus, B. subtilis, E. coli, P. aeruginosa, K. pneumoniae and $Y$. enterocolitica, with inhibition halos ranging from 16 to $20 \mathrm{~mm}$. Compatible values with those observed in the present work for the tested Gram-positive species. Among the Myrtaceae family, Boulekbache-Makhlouf, Slimani and Madani (2013) reported the antimicrobial activity of Tasmanian eucalyptus fruits against S. aureus $(14.67 \mathrm{~mm})$ and B. subtilis $(11.5 \mathrm{~mm})$ and Medina et al. (2011) reported the antimicrobial activity of the aqueous extract of yellow araçá and red araçá against $S$. Enteritidis (15.3 and $17 \mathrm{~mm}$, respectively). The antimicrobial activity of Tasmanian eucalyptus fruits is equivalent to those reported for the Campomanesia species studied in the present work. 
Table 2. Average diameter of inhibition zone \pm standard deviation (mm) of Campomanesia eugenioides, Campomanesia xanthocarpa (Berg) and Campomanesia xanthocarpa var. littoralis (D. Landrum) fruit extracts, positive and negative controls ${ }^{\dagger}$.

\begin{tabular}{|c|c|c|c|c|c|c|}
\hline & C. eugenioides & C. xanthocarpa (Berg) & C. xanthocarpa var. littoralis & Amp & Chlo & DMSO \\
\hline \multicolumn{7}{|l|}{ Gram (+) } \\
\hline Bacillus cereus ATCC 11778 & $14.0 \pm 0.0^{c}$ & $13.0 \pm 0.0^{\mathrm{d}}$ & $15.0 \pm 0.0^{\mathrm{b}}$ & $14.7 \pm 0.6^{\mathrm{bc}}$ & $30.0 \pm 0.0^{\mathrm{a}}$ & - \\
\hline Bacillus subtilis ATCC 6633 & $14.0 \pm 0.0^{c}$ & $13.7 \pm 0.6^{\mathrm{c}}$ & $16.0 \pm 0.0^{\mathrm{b}}$ & $30.0 \pm 0.0^{\mathrm{a}}$ & $31.0 \pm 1.1^{\mathrm{a}}$ & - \\
\hline Listeria monocytogenes ATCC 19117 & $12.3 \pm 0.6^{\mathrm{c}}$ & $12.0 \pm 0.0^{\mathrm{c}}$ & $12.7 \pm 0.5^{\mathrm{c}}$ & $31.7 \pm 0.6^{\mathrm{a}}$ & $28.0 \pm 1.1^{\mathrm{b}}$ & - \\
\hline Listeria monocytogenes ser 2 ATCC 19112 & $15.3 \pm 0.6^{\mathrm{c}}$ & $14.3 \pm 0.6^{\mathrm{c}}$ & $15.7 \pm 0.5^{\mathrm{c}}$ & $39.3 \pm 0.6^{\mathrm{a}}$ & $27.0 \pm 0.6^{\mathrm{b}}$ & - \\
\hline Staphylococcus aureus ATCC 29213 & $14.0 \pm 0.0^{\mathrm{e}}$ & $18.3 \pm 0.6^{\mathrm{c}}$ & $15.0 \pm 0.0^{\mathrm{d}}$ & $22.7 \pm 0.6^{b}$ & $25.0 \pm 0.0^{\mathrm{a}}$ & - \\
\hline Staphylococcus aureus ATCC 6538 & $19.3 \pm 0.6^{\mathrm{c}}$ & $13.3 \pm 0.6^{\mathrm{e}}$ & $16.0 \pm 0.0^{\mathrm{d}}$ & $42.7 \pm 0.6^{\mathrm{a}}$ & $29.0 \pm 0.6^{b}$ & - \\
\hline Staphylococcus aureus ATCC 25923 & $15.0 \pm 0.0^{\mathrm{d}}$ & $13.5 \pm 0.5^{\mathrm{e}}$ & $16.8 \pm 0.2^{c}$ & $32.7 \pm 0.6^{\mathrm{a}}$ & $29.0 \pm 1.0^{\mathrm{b}}$ & - \\
\hline \multicolumn{7}{|l|}{ Gram (-) } \\
\hline Enterobacter aerogenes ATCC 13048 & - & - & - & - & $27.0 \pm 1.0$ & - \\
\hline Escherichia coli ATCC 25922 & - & - & - & $20.0 \pm 0.0^{b}$ & $29.0 \pm 1.0^{\mathrm{a}}$ & - \\
\hline Proteus vulgaris ATCC 13315 & - & - & - & $30.7 \pm 0.6^{\mathrm{a}}$ & $27.0 \pm 1.1^{\mathrm{b}}$ & - \\
\hline Pseudomonas aeruginosa ATCC 27853 & - & - & - & - & - & - \\
\hline Salmonella Enteritidis ATCC 13076 & - & - & - & $25.7 \pm 0.6^{\mathrm{b}}$ & $29.0 \pm 0.5^{\mathrm{a}}$ & - \\
\hline Salmonella Typhimurium ATCC 14028 & - & - & - & $26.0 \pm 0.0^{\mathrm{b}}$ & $27.0 \pm 0.6^{\mathrm{a}}$ & - \\
\hline Shigella sonnei ATCC 25931 & - & - & - & $23.0 \pm 0.0^{b}$ & $29.0 \pm 1.0^{\mathrm{a}}$ & - \\
\hline Yersinia enterocolitica ATCC 9610 & - & - & - & $24.0 \pm 0.0^{b}$ & $33.0 \pm 0.6^{\mathrm{a}}$ & - \\
\hline
\end{tabular}

Results presented as mean \pm SD, $n=3$. The same letters in the same line indicate no significant difference (P < 0.05). (-) - Without inhibition zone. Amp - ampicillin; Chlo chloramphenicol; DMSO - dimethyl sulfoxide. Source: The authors (2020). 
Figure 1. Inhibition zone of C. eugenioides, C. xanthocarpa (Berg), and C. xanthocarpa var. littoralis fruit extracts against Listeria monocytogenes ATCC 19117 and Listeria monocytogenes ser 2 ATCC 19112. The white disk represents the negative control with DMSO.

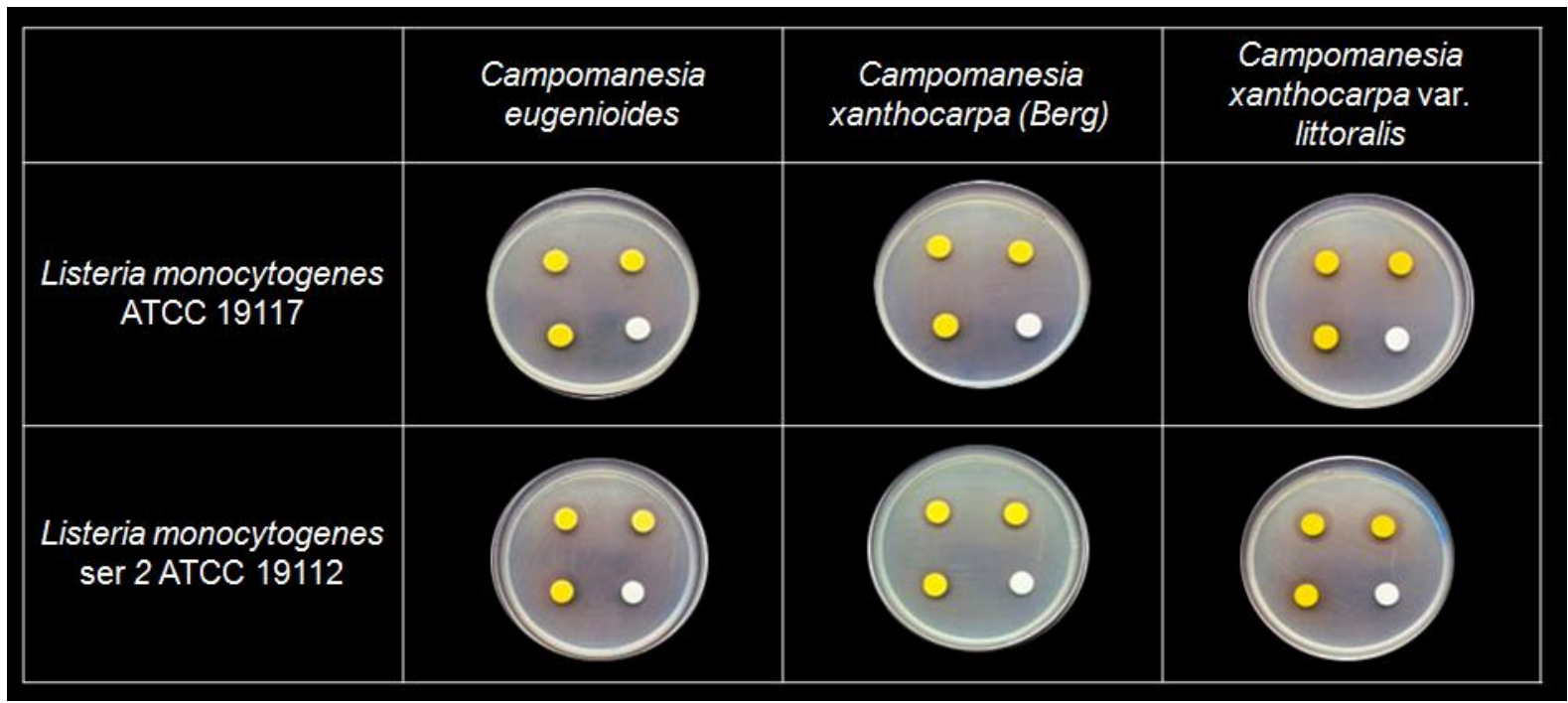

Source: The authors (2020).

Figure 2. Inhibition zone of C. eugenioides, C. xanthocarpa (Berg), and C. xanthocarpa var. littoralis fruit extracts against Staphylococcus aureus ATCC 29213, Staphylococcus aureus ATCC 6538 and Staphylococcus aureus ATCC 25923. The white disk represents the negative control with DMSO.

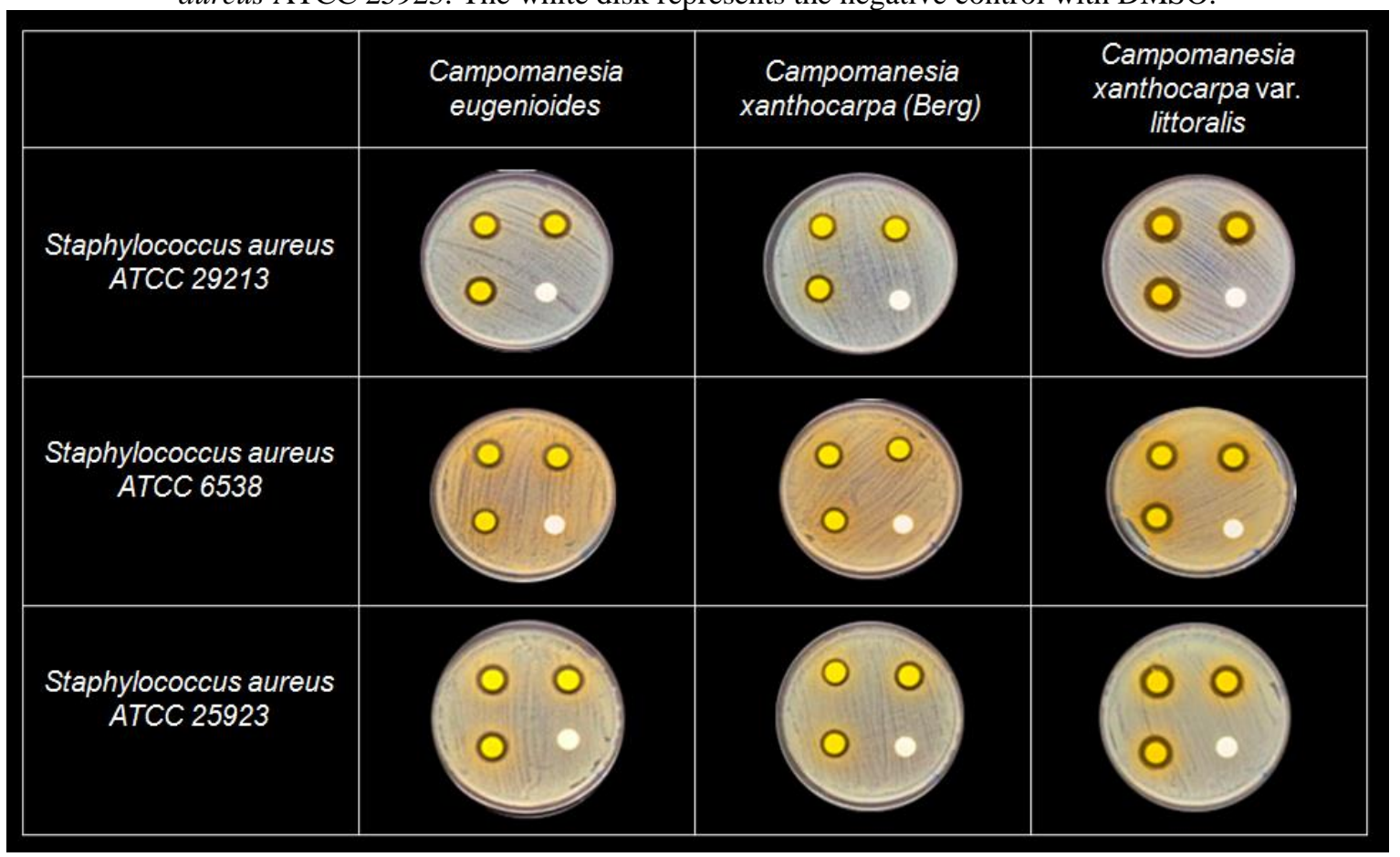

Source: The authors (2020). 
Figure 3. Inhibition zone of C. eugenioides, C. xanthocarpa (Berg), and C. xanthocarpa var. littoralis fruit extracts against Bacillus cereus and Bacillus subtilis. The white disk represents the negative control with DMSO.

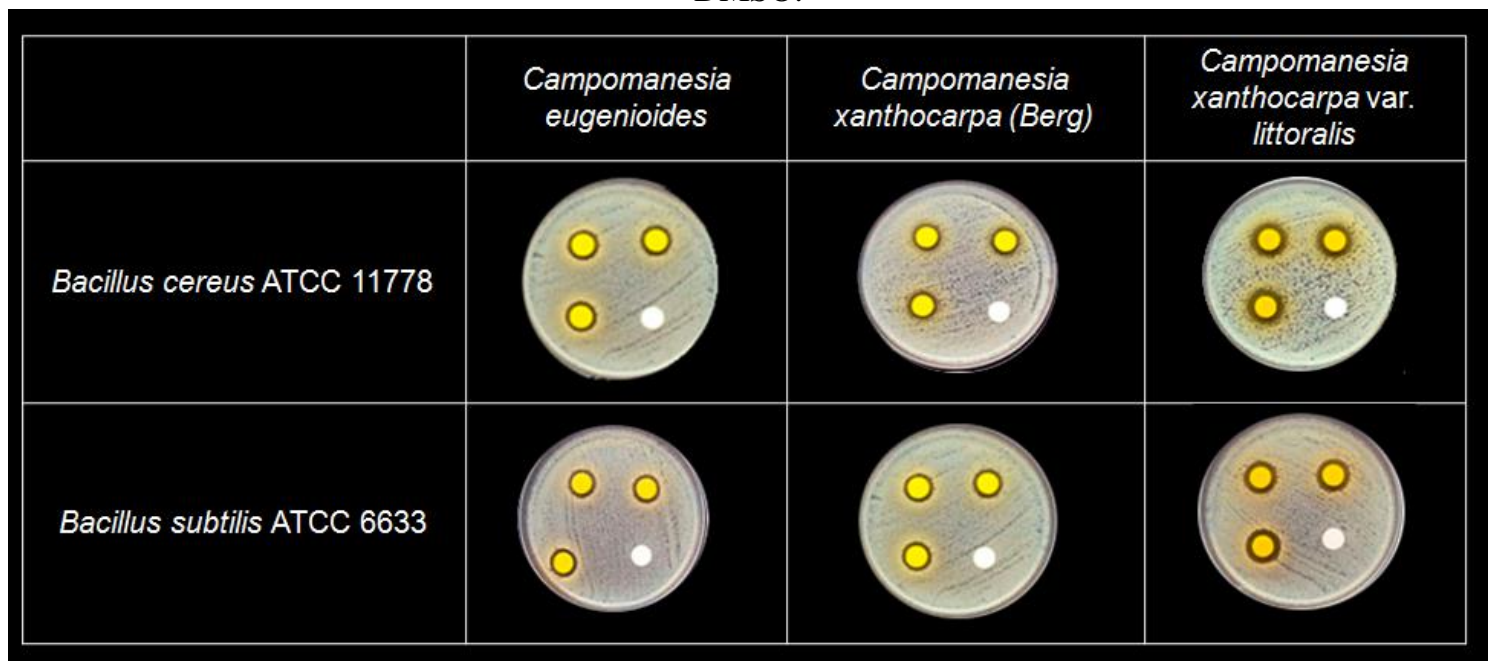

Source: The authors (2020).

Minimum inhibitory concentrations (MIC) and minimum bactericidal concentrations (MBC) were determined for the bacteria species that showed susceptibility in the disk diffusion method, and these results are shown in Table 3. In general, all fruit extracts showed good antibacterial activity against all species of bacteria tested, with emphasis on the MBC of $C$. eugenioides against Bacillus cereus and B. subtilis; C. xanthocarpa (Berg) against S. aureus ATCC 29213; and C. xanthocarpa var. littoralis against B. subtilis and L. monocytogenes serotype 2. Figure 4 shows the microdilution plate for the MIC test of $C$. xanthocarpa against S. aureus ATCC 29213 and S. aureus ATCC 6538.

Table 3. Minimum inhibitory concentrations (MIC) and minimum bactericidal concentrations (MBC) $\left(\mathrm{mg} \mathrm{mL}^{-1}\right)$ of Campomanesia eugenioides, Campomanesia xanthocarpa (Berg) and Campomanesia xanthocarpa var. littoralis (D. Landrum) fruit extracts ${ }^{a}$.

\section{C. eugenioides C. xanthocarpa (Berg) C. xanthocarpa var. littoralis}

\begin{tabular}{lcccccc} 
& MIC & MBC & MIC & MBC & MIC & MBC \\
\hline Bacillus cereus & 0.62 & 0.62 & 0.62 & 10.00 & 0.31 & 1.25 \\
Bacillus subtilis & 0.62 & 0.62 & 0.62 & 10.00 & 0.31 & 0.62 \\
Listeria monocytogenes & 1.25 & 2.50 & 0.62 & 1.25 & 0.62 & 1.25 \\
Listeria monocytogenes sor 2 & 1.25 & 2.50 & 0.62 & 1.25 & 0.62 & 0.62 \\
Staphylococcus aureus ATCC 29213 & 1.25 & 1.25 & 0.62 & 0.62 & 0.31 & 1.25 \\
Staphylococcus aureus ATCC 6538 & 1.25 & 1.25 & 0.62 & 1.25 & 0.31 & 1.25 \\
Staphylococcus aureus ATCC 25923 & 1.25 & 1.25 & 0.62 & 2.50 & 0.31 & 1.25 \\
\hline
\end{tabular}

${ }^{a}$ Results presented as modal value, $\mathrm{n}=3$. Source: The authors (2020). 
Figure 4. Result of the minimum inhibitory concentration (MIC) of the extract of $C$. xanthocarpa in DMSO against Staphylococcus aureus ATCC 29213 and Staphylococcus aureus ATCC 6538.

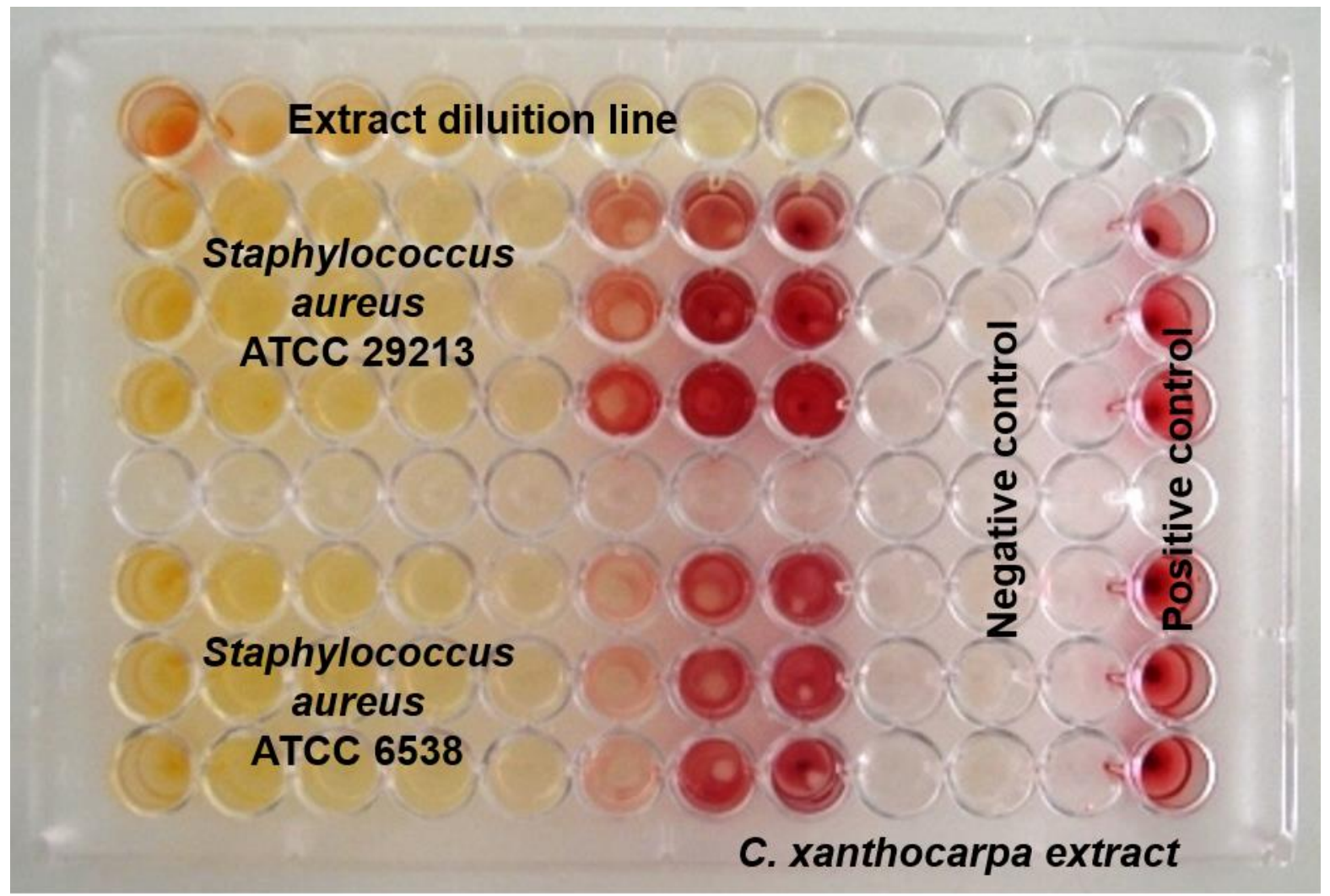

Source: The authors (2020).

For hexanic extracts of the fruits of $C$. pubescens and C. adamantium, Cardoso et al. (2010) reported minimal inhibitory concentrations in the range of 5 to $20 \mu \mathrm{g} \mathrm{mL}^{-1}$ for four species of bacteria ( $S$. aureus, $P$. aeruginosa, E. coli and Salmonella Setúbal) and two yeasts (Saccharomyces cerevisiae and Candida albicans). The authors observed lower MIC values for the bacterium $S$. aureus $\left(15 \mu \mathrm{g} \mathrm{mL}^{-1}\right)$ compared to the results described in the present study. They also present, for P. aeruginosa, MIC of $15 \mu \mathrm{g} \mathrm{mL}^{-1}$ and for E. coli MIC of $20 \mu \mathrm{g} \mathrm{mL}^{-1}$, bacteria that were not susceptible to the extracts of the fruits of this study by the agar diffusion technique. Therefore, it is evident that the genus Campomanesia presents antimicrobial properties against potentially pathogenic bacteria to humans.

Cavanagh, Hipwell and Wilkinson (2003) observed strong antimicrobial activity of raspberry, cranberry, blackberry and currant against E. faecalis, E. coli, P. aeruginosa, S. Enteritidis, $S$. Typhimurium, $S$. sonnei and $S$. aureus. It can be seen, therefore, that fruits of different species (including those of the genus Campomanesia) have antimicrobial capacity and could be used as adjuvants in treatments of bacteriosis caused by the consumption of contaminated food. 
Regarding other fruits of the Myrtaceae family, studies on Serrana guava are reported. Basile et al (1997) presented MIC for S. aureus $\left(8 \mu \mathrm{g} \mathrm{mL}^{-1}\right), P$. aeruginosa $\left(1 \mu \mathrm{g} \mathrm{mL}^{-1}\right)$, E coli $\left(1 \mu \mathrm{g} \mathrm{mL}^{-1}\right)$ while in relation to MBC the maximum concentration of the extract used was not effective (1000 $\mathrm{g} \mathrm{mL}^{-1}$ ). Vuotto et al. (2000) observed for $S$. aureus MIC of $64 \mathrm{mg} \mathrm{L}^{-1}$ and MBC not detected, for E. coli MIC of $4 \mathrm{mg} \mathrm{L}^{-1}$ and $\mathrm{MBC}$ of $32 \mathrm{mg} \mathrm{L}^{-1}$, for P. vulgaris MIC of $8 \mathrm{mg} \mathrm{L}^{-1}$ and $\mathrm{MBC}$ of $64 \mathrm{mg} \mathrm{L}^{-1}$, for $P$. aeruginosa $\mathrm{MIC}$ of $1 \mathrm{mg} \mathrm{L}^{-1}$ and $\mathrm{MBC}$ of $8 \mathrm{mg} \mathrm{L}^{-1}$ and for E. aerogenes MIC of $2 \mathrm{mg} \mathrm{L}^{-1}$ and $\mathrm{MBC}$ of $16 \mathrm{mg} \mathrm{L}^{-1}$. In the light of these observations, according to Cardoso et al. (2010), the extraction protocol could be improved using other extraction solvents to obtain better results against Gram-negative bacteria.

The antimicrobial activity shown by fruits is mainly due to the presence of secondary metabolites in its composition, such as phenolic compounds, among them the flavonoids that have antimicrobial activity reported in the literature (HARBORNE; WILLIAMS, 2000; CUSHNIE; LAMB, 2005; 2011). Finally, the results obtained in our study, lead us to believe that the phenolic and flavonoids compounds from C. eugenioides, C. xanthocarpa (Berg) and C. xanthocarpa var. littoralis are primarily responsible by the antibacterial activity observed. The data reported depicting the potential use of these three Campomanesia species as antibacterial agents, and the role they may play in their future application fields aiming to generate a functional food.

\section{Final Considerations}

This study will provide important scientific data supporting the application of valuable fruits from three edible Campomanesia species for producing bioactive ingredients and natural preservatives for food products. C. eugenioides, C. xanthocarpa (Berg), and C. xanthocarpa var. littoralis showed distinct antimicrobial characteristics. All the three extracts had no antibacterial activity against the eight species of Gram-negative bacteria tested. Nevertheless, all Gram-positive bacteria tested were susceptible to the three fruit extracts, where $C$. xanthocarpa var. littoralis fruit extract demonstrated high inhibitory activity against a more substantial number of Gram-positive bacteria. We concluded that the phenolic and flavonoids compounds of C. eugenioides, C. xanthocarpa (Berg) and C. xanthocarpa var. littoralis are primarily responsible by the antibacterial activity detected. Thus, our results contribute to the discovery of the potential application of these native Campomanesia Brazilian fruits, as a natural product with antibacterial properties. 


\section{Conflicts of interest statement}

Authors declare no conflicts of interest in this manuscript.

\section{Acknowledgments}

The authors acknowledge financial support from FAPESC (08/2009, process FCTP 3302/091). The authors also gratefully thank to A. Dalla Rosa and J. Oliveira for providing the samples, and to Dr. A. Jasper (UNIVATES, RS, Brazil) for the botanical identification of the samples.

\section{Author's contributions}

All authors contributed extensively to the work presented in this manuscript. S.V. and S.M.S.: Designed and performed research, wrote and revised the manuscript. A.C.J.: Contributed to the development of experimental part and reviewed the manuscript. N.F.: Helped in design research and discussion. J.C.B.: performed the species identification. All authors read and approved the final manuscript.

\section{References}

AHMAD, I., MEHMOOD, Z., MOHAMMAD, F. Screening of some Indian medicinal plants for their antimicrobial properties. Journal of Ethnopharmacology, v. 62, p. 183-193, 1998.

AL-ZOREKY,N.S. Antimicrobial activity of pomegranate (Punica granatum L.) fruit peels. International Journal of Food Microbiology, v. 134, p. 244-248, 2009.

BARBIERI, S. F. et al. Extraction, purification and structural characterization of a galactoglucomannan from the gabiroba fruit (Campomanesia xanthocarpa Berg), Myrtaceae family. Carbohydrate Polymers, v. 174, p. 887-895, 15 out. 2017.

BARROS, R. G. C. et al. Evaluation of bioactive compounds potential and antioxidant activity in some Brazilian exotic fruit residues. Food Research International, v. 102, p. 8492, 1 dez. 2017.

BASILE, A. et al. Antibacterial activity in Actinidia chinensis, Feijoa sellowiana and Aberia caffra. Internactional Journal of Antimicrobial Agents, v. 8, p. 199-203, 1997.

BIAVATTI, M. . et al. Preliminary studies on Campomanesia xanthocarpa (Berg.) and Cuphea carthagenensis (Jacq.) J.F. Macbr. aqueous extract: weight control and biochemical parameters. Journal of Ethnopharmacology, v. 93, n. 2-3, p. 385-389, ago. 2004.

BOULEKBACHE-MAKHLOUF, L., SLIMANI, S., MADANI, K. TOTAL phenolic content, antioxidant and antibacterial activities of fruits of Eucalyptus globulus cultivated in Algeria. 
Industrial Crops and Products, v. 41, p. 85- 89, 2013.

BRANDAO, M. P.; ANJOS, V. de C. dos; BELL, M. J. V. Time resolved fluorescence of cow and goat milk powder. Spectrochimica Acta - Part A: Molecular and Biomolecular Spectroscopy, v. 171, p. 193-199, 2017.

CARDOSO, C. A. L. et al. Antimicrobial Activity of the Extracts and Fractions of Hexanic Fruits of Campomanesia Species (Myrtaceae). Journal of Medicinal Food, v. 13, n. 5, p. 1273-1276, 2010.

CAROVIĆ-STANKO, K. et al. Composition and antibacterial activities of essential oils of seven Ocimum taxa. Food Chemistry, v. 119, n. 1, p. 196-201, 2010.

CAVANAGH, H. M. A.; HIPWELL, M.; WILKINSON, J. M. Antibacterial activity of berry fruits used for culinary purposes. Journal of Medicinal Food. V. 6, n. 1, 2003.

CELIKTAS, O. Y. et al. Antimicrobial activities of methanol extracts and essential oils of Rosmarinus officinalis, depending on location and seasonal variations. Food Chemistry, v. 100, n. 2, p. 553-559, 2007.

CLSI. Methods for dilution antimicrobial susceptibility tests for bacteria that grow aerobically; approved standard. 8. ed. Pennsylvania, USA: CLSI document M7-A6, 2019a.

CLSI. Performance standards for antimicrobial disk susceptibility tests: approved standard. 8. ed. Pennsylvania, USA: CLSI document M2-A8, 2019b.

CUSHNIE, T. P. T.; LAMB, A. J. Antimicrobial activity of flavonoids. International Journal of Antimicrobial Agents, v. 26, p. 343-356, 2005.

CUSHNIE, T. P. T.; LAMB, A. J. Recent advances in understanding the antibacterial properties of flavonoids. International Journal of Antimicrobial Agents, v. 38, n. 2, p. 99 107, ago. 2011.

CUSHNIE, T. P. T.; LAMB, A. J. Recent advances in understanding the antibacterial properties of flavonoids. International Journal of Antimicrobial Agents, v. 38, p. 99- 107, 2011.

DONADO-PESTANA, C. M. et al. Polyphenols from Brazilian native Myrtaceae fruits and their potential health benefits against obesity and its associated complications. Current Opinion in Food Science, v. 19, p. 42-49, 1 fev. 2018.

DRAGIŠIĆ MAKSIMOVIĆ, J. J. et al. Profiling antioxidant activity of two primocane fruiting red raspberry cultivars (Autumn bliss and Polka). Journal of Food Composition and Analysis, v. 31, n. 2, p. 173-179, 1 set. 2013.

DRÖGE, W. Free Radicals in the Physiological Control of Cell Function. Physiological Reviews, v. 82, n. 1, p. 47-95, jan. 2002.

HARBORNE, J. B.; WILLIAMS, C. A. Advances in flavonoid research since 1992. Phytochemistry, v. 55, p. 481-504, 2000. 
LANCETTE, G. A., BENNET, R. W. Staphylococcus aureus and staphylococcal enterotoxins. In: DOWNES, F. P.; ITO, K. Compendium of methods for the microbiological examination of foods. 4 ed. Washington: APHA, cap. 36, p. 343-363, 2001.

LIMA, D. F. et al. O gênero Campomanesia (Myrtaceae) no estado do Paraná, Brasil. Rodriguésia, v. 62, n. 3, p. 683-693, set. 2011.

MALANOVIC, N.; LOHNER, K. Antimicrobial Peptides Targeting Gram-Positive Bacteria. Pharmaceuticals (Basel, Switzerland), v. 9, n. 3, 20 set. 2016.

MEDINA, A. L. et al. Araçá (Psidium cattleianum Sabine) fruit extracts with antioxidant and antimicrobial activities and antiproliferative effect on human cancer cells. Food Chemistry, v. 128, p. 916-922, 2011.

MOURA-COSTA, G. F. et al. Antimicrobial activity of plants used as medicinals on an indigenous reserve in Rio das Cobras, Parana, Brazil. Journal of Ethnopharmacology, v. 143, n. 2, p. 631-638, 2012.

PAZ, M. et al. Brazilian fruit pulps as functional foods and additives: Evaluation of bioactive compounds. Food Chemistry, v. 172, p. 462-468, 1 abr. 2015.

PEREIRA, M. C. et al. Characterization, bioactive compounds and antioxidant potential of three Brazilian fruits. Journal of Food Composition and Analysis, v. 29, n. 1, p. 19-24, 1 fev. 2013.

RYSER, E. T.; DONNELLY, C. W. Listeria. In: DOWNES, F. P.; ITO, K. Compendium of methods for the microbiological examination of foods. 4 ed. Washington: APHA, cap. 36, p. 343-363, 2001.

SILVEIRA, S. M. et al. Chemical composition and antibacterial activity of Laurus nobilis essential oil towards foodborne pathogens and its application in fresh Tuscan sausage stored at $7{ }^{\circ}$ C. LWT - Food Science and Technology, v. 59, n. 1, p. 86-93, nov. 2014.

VALLILO, M. I. et al. Composição química dos frutos de Campomanesia xanthocarpa BergMyrtaceae. Ciência e Tecnologia de Alimentos, v. 28, p. 231-237, 2008.

VUOTTO, M.L. et al. Antimicrobial and antioxidant activities of Feijoa sellowiana fruit. International Journal of Antimicrobial Agents, v.13, p.197-201, 2000. 